\title{
Detection of Pathogenic Bacteria in Skin Lesions of Patients with Chiclero's Ulcer. Reluctant Response to Antimonial Treatment
}

\author{
Angélica Patricia Isaac-Márquez, Claudio Manuel Lezama-Dávila ${ }^{+}$ \\ Centro de Investigaciones en Enfermedades Tropicales, Universidad Autónoma de Campeche, Av. Agustín Melgar s/n, \\ 24030 Campeche, México
}

We investigated the bacterial flora present in skin lesions of patients with chiclero's ulcer from the Yucatan peninsula of Mexico using conventional culture methods (11 patients), and an immunocolorimetric detection of pathogenic Streptococcus pyogenes (15 patients). Prevalence of bacteria isolated by culture methods was $90.9 \%$ (10/11). We cultured, from chiclero's ulcers (60\%), pathogenic bacterial such as Staphylococcus aureus (20\%), S. pyogenes (1.6\%), Pseudomonas aeruginosa (1.6\%), Morganella morganii (1.6\%), and opportunist pathogenic bacteria such as Klebsiella spp. (20.0\%), Enterobacter spp. (20\%), and Enterococcus spp. (20\%). We also cultured coagulase-negative staphylococci in 40\% (4/10) of the remaining patients. Micrococcus spp. and coagulasenegative staphylococci constituted the bacterial genuses more frequently isolated in the normal skin of patients with chiclero's ulcer and healthy individuals used as controls. We also undertook another study to find out the presence of S. pyogenes by an immunocolorimetric assay. This study indicated that 60\% (9/15) of the ulcerated lesions, but not normal controls, were contaminated with S. pyogenes. Importantly, individuals with purulent secretion and holding concomitant infections with S. pyogenes, S. aureus, P. aeruginosa, M. morganii, and E. durans took longer to heal Leishmania (L.) mexicana infections treated with antimonial drugs. Our results suggest the need to eliminate bacterial purulent infections, by antibiotic treatment, before starting antimonial administration to patients with chiclero's ulcer.

Key words: chiclero's ulcer - bacterial flora - antimonial treatment - Mexico

Chiclero's ulcer, one of the existing forms of cutaneous leishmaniosis (CL), is due to infection mainly by Leishmania (Leishmania) mexicana and is mostly present in Southern Mexico and Central America (Pérez Mutul et al. 1994). The disease mechanisms responsible for healing or chronicity of experimental and human leishmaniosis are essentially confined to the immune system (Shankar \& Titus 1995, Lezama-Dávila et al. 1998). Bacterial, fungal, viral and parasitic infections sometimes result as illnesses affecting the integrity of skin and immune system (Couppie 1997, Grasa et al. 2000, Nega et al. 2001). When nodules due to infection with Leishmania parasites ulcerate, they become susceptible to colonization with a number of microorganisms, such as pathogenic fungus and bacterial that could provoke secondary infections. Studies carried out in Iran and Ecuador have documented the presence of bacterial infections associated with cutaneous lesions in patients with CL that include a number of pathogenic bacterial (Edrissian et al. 1990, Kawabata et al. 1995).

Financial support: Secretaría de Educación Pública (FOMES 94-04-03-01) and University of Campeche

${ }^{+}$Corresponding author. Present address: Av. Universidad No. 6, Fraccionamiento Bosques de Campeche, 24030 Campeche, México.

Fax.: +52-981-81-2-02-68. E-mail: vanity@ prodigy.net.mx Received 3 June 2003

Accepted 13 October 2003
The aim of the present work was to investigate the presence of pathogenic bacterial in lesions of patients with chiclero's ulcer, in relation to effectiveness of antimonial treatment and the pattern of susceptibility to antimicrobials. The criteria for inclusion of patients in this work was based on a positive clinical diagnosis of chiclero's ulcer together with laboratory analysis, as reported elsewhere (Lezama-Dávila et al. 1998). These laboratory tests included the induction of a DTH response and parasite identification by lesion smears stained with Giemsa. Bacterial culture was performed in different groups: one group included bacteriological culture of samples from different ulcerated lesions or normal skin of 11 patients with chiclero's ulcer. Another group consisted of 11 samples from normal skin of healthy controls. An additional group under study included samples from ulcerated lesions from 15 patients with chiclero's ulcer that were not submitted to bacteriological culture, but were tested by a more sensitive immunocolorimetric assay: Group A Strep SMART ${ }^{\mathrm{TM}}$ (Sensitive membrane antigen rapid test, New Horizons Diagnostics, Co.), aimed to detect pathogenic Streptococcus pyogenes. Culture and identification of bacteria present in chiclero's ulcers was performed as follows: after appropriate cleaning, ulcer's specimens were obtained by rubbing two sterile cotton swabs moistened with sterile saline solution over the edge of ulcerated lesions. One of which was inserted in Stuart's transport medium and, with the remaining swab, we performed two smears over glass slides that were stained with Gram to detect bacterial. Specimens were 
cultured in tryptic soy agar (Difco, Mexico) supplemented with 5\% sheep blood (In Vitro, Mexico) and MacConkey agar (Difco) and were then incubated at $37^{\circ} \mathrm{C}$ for $24 \mathrm{~h}$. Smears from each of the morphologically different colonies selected from culture mediums were treated with Gram's stain and were microscopically examined as reported by Cheesbrough (1989). The catalase test (Difco) was practiced to gram-positive organisms, whereas the cytochrome oxidase test (Difco) was practiced to gramnegative organisms. The final identification of genuses, species, biotypes and pattern of antibiotic resistance of the isolated microorganisms was carried out with the PASCO system (Difco). Medical care of patients was performed by general practitioners appointed by the local health authorities. Once diagnosis was performed and confirmed by laboratory tests, patients received daily intramuscular injections of $1.5 \mathrm{~g}$ of antimoniate of meglumine (Glucantime ${ }^{\mathrm{TM}}$ ) for 20 days. This course of treatment was repeated up to three times (as needed) if cutaneous lesions showed no signs of healing.

Results from this work showed that $50 \%$ of patients presented lesions located in the ear and, in the remaining cases, the anatomical location of lesions varied including the back, the eyelid, and the extremities. Parasites were detected in lesion smears in all the 26 patients and all of them displayed a positive DTH (e.g. $\geq 0.5 \mathrm{~cm}$ of skin induration; mean $\pm \mathrm{sem}=0.75 \pm 0.083 \mathrm{~cm}$, range $=0.5-1.2 \mathrm{~cm}$ ). The presence of cultured bacterial flora was documented in lesions of 10 out of 11 patients with chiclero's ulcer included in this study. Table shows the bacterial flora isolated from ulcerated lesions, normal skin near the lesion, and normal skin from healthy donors. The distribution patterns of bacterial families that we found in this study is as follows: Micrococcaceae family pre-dominated, $47 \%(8 / 17)$ of the isolated strains corresponded to the genus Staphylococcus, whereas 29\% and 17\% belonged to Enterobacteriaceae and Streptococcaceae family, respectively. The presence of pathogenic bacteria was documented in samples taken from Leishmania skin lesions, and when purulent secretions were present antimonial treatment needed two more schedules of 20 injections each one to cure the parasite infection. The pattern of resistance of isolated strains to common antibiotics for grampositive and gram-negative bacterial was also performed. Species of Staphylococcus from ulcerated lesions including $S$. aureus were resistant to ampicillin, penicillin, and cefixime. Forty four percent of these microorganisms also presented resistance to erythromycin. S. pyogenes presented resistance to the aminoglycosides, trimethoprim/ sulfamethoxazole, and lomefloxacin. This strain was also

TABLE

Genus, species and biotype of bacterial flora isolated

\begin{tabular}{|c|c|c|c|c|}
\hline \multirow{3}{*}{$\begin{array}{l}\mathrm{Nr} \\
\text { patient }\end{array}$} & \multirow{2}{*}{\multicolumn{2}{|c|}{ Humans with chiclero's ulcer }} & \multirow{3}{*}{$\begin{array}{l}\mathrm{Nr} \text { of } \\
\text { healthy } \\
\text { control }\end{array}$} & \multirow{3}{*}{$\begin{array}{l}\text { Healthy controls } \\
\text { Normal skin from the same } \\
\text { anatomical location of lesions }\end{array}$} \\
\hline & & & & \\
\hline & Ulcerated lesions & Normal skin near the lesion & & \\
\hline 1 & $\begin{array}{l}\text { E. faecalis } 2730770 \\
\text { E. agglomerans } 773202511\end{array}$ & S. hominis 0042362 & 1 & $\begin{array}{l}\text { Micrococcus spp. } 0044322 \\
\text { Micrococcus spp. } 0002102\end{array}$ \\
\hline 2 & ND & S. hominis 0042162 & 2 & S. hominis 1042162 \\
\hline 3 & $\begin{array}{l}\text { S. auricularis } 0020132 \\
\text { S. cohnni sub. } 10104372\end{array}$ & Micrococcus spp. 0044322 & 3 & $\begin{array}{l}\text { S. epidermidis } 1146562 \\
\text { P. aeruginosa } 202034016\end{array}$ \\
\hline 4 & K. ozaenae 377700400 & K. ozaenae 377700400 & 4 & $\begin{array}{l}\text { S. epidermidis } 4106162 \\
\text { S. haemolyticus } 0102362\end{array}$ \\
\hline $5^{a}$ & S. aureus 1526362 & S. epidermidis 1146762 & 5 & $\begin{array}{l}\text { S. epidermidis } 1146762 \\
\text { K. ozaenae } 377700400\end{array}$ \\
\hline 6 & $\begin{array}{l}\text { E. cloacae } 777737753 \\
\text { K. pneumoniae } 777727311\end{array}$ & $\begin{array}{l}\text { E. agglomerans } 377700040 \\
\text { K. rhinoscleromatis } 377700401\end{array}$ & 6 & S. haemolyticus 0003322 \\
\hline $7^{a}$ & $\begin{array}{l}\text { E. durans } 3730370 \\
\text { M. morganii } 600014027 \\
\text { P. aeruginosa } 242434056\end{array}$ & Micrococcus spp. 0002102 & 7 & S. hominis 0002162 \\
\hline 8 & $\begin{array}{l}\text { S. cohnni sub. } 10104372 \\
\text { S. xylosus } 1546373\end{array}$ & $\begin{array}{l}\text { S. warneri } 6502162 \\
\text { P. putida } 202034012\end{array}$ & 8 & $\begin{array}{l}\text { S. simulans } 1143362 \\
\text { S. hominis } 0042362\end{array}$ \\
\hline 9 & S. epidermidis 1106562 & Micrococcus spp. 0006322 & 9 & $\begin{array}{l}\text { S. hominis } 0042162 \\
\text { S. warneri } 0142162 \\
\text { S. warneri } 6502162\end{array}$ \\
\hline $10^{a}$ & $\begin{array}{l}\text { S. aureus } 1506363 \\
\text { S. pyogenes } 3106301\end{array}$ & S. simulans 1122362 & 10 & $\begin{array}{l}\text { E. agglomerans } 377700040 \\
\text { K. rhinoscleromatis } 377700401\end{array}$ \\
\hline 11 & S. saprophyticus 0442372 & S. saprophyticus 0442372 & 11 & $\begin{array}{l}\text { P. putida } 202034012 \\
\text { P. fluorescens } 202014002 \\
\text { P. shigelloides } 342734012\end{array}$ \\
\hline
\end{tabular}

$a$ : patients with purulent lesions; ND: not detected 
resistance to three clinically important antibiotics (penicillin, vancomycin, and erythromycin). S. pyogenes, was detected in cutaneous lesions of $60 \%(9 / 15)$ of patients but was not found in normal skin suggesting the development of a concomitant bacterial infection in patients with chiclero's ulcer. S. aureus was isolated in $20 \%(2 / 10)$ of ulcerated lesions, but was not found in normal skin of healthy individuals. This bacteria was also isolated from a purulent secretion located in a typical Leishmania skin lesion, and in two other purulent lesions a mixed flora was found and was represented in one case by $S$. pyogenes and $S$. aureus and, in the other, by $P$. aeruginosa, $M$. morganii, and E. durans. We also isolated from skin lesions Enterobacter spp., Klebsiella spp., and Enterococcus spp. which could play an opportunist role. We concluded that presence of pathogenic bacteria, in purulent chiclero's ulcers, is strongly suggestive of a concomitant bacterial infection. However, in normal skin, only coagulase negative staphylococci and Micrococcus spp. were isolated. The presence in CL patients of Staphylococcus spp., Streptococcus $\beta$-haemolyticus, Enterococcus spp., and gram-negative organisms as Enterobacter spp., Klebsiella spp., and Pseudomonas spp., has been reported by Edrissian et al. (1990) and Kawabata et al. (1995). These results coincide with those obtained in this study. However, in contrast to our results, these authors also reported the presence of E. coli, Serratia spp., Proteus spp., Acinetobacter spp., and Alcaligenes spp. Bacteria such as $S$. aureus and $P$. multocida have also been found contaminating CL lesions in golden hamsters infected with L. brasiliensis (Potter et al. 1983) and in BALB/ c mice infected with L. major (El-On et al 1992) that worsened the disease and interfered with the healing process. S. pyogenes constitute a pathogenic bacteria commonly found in the throat and skin (Cheesbrough 1989). S. aureus is responsible for abscesses, styes, and impetigo, it may also cause secondary infections provoked by insect bites, ulcers, burns, wounds, and skin disorders (Cheesbrough 1989). Identification of $S$. epidermidis also presents clinical relevance as reported by Roth and James (1988). According to the results of this work, ulcerated lesions characteristic of patients with chiclero's ulcer are frequently colonized with intestinal or environmental bacterial that might affect the development of infections with L. mexicana. The bacterial flora isolated from humans infected with $L$. mexicana could be the result of interactions with their environment that are determined by farming and other occupations performed in the rain forest. El-On et al. (1992) reported that Leishmania parasites and their metabolites might induce a local immunosuppression in the CL lesion experimentally produced by L. major. It is possible that in the human infection due to L. mexicana this phenomenon of immunosuppression could be present and may facilitate concomitant bacterial infections. Chiclero's ulcer affects residents of rural areas which, in most cases, live far away from health care centres. It is common that they undertake empirical remedies and sometimes receive antibiotic drugs indiscriminately. This favor the phenomenon of multiple resistance to antibiotics. In this study $50 \%(9 / 18)$ of isolated strains from lesions of patients with chiclero's ulcer showed resistance to five or more drugs. This could favor the indication of antibiotic susceptibility test to improve drug therapy.

Finally, results obtained in this study suggest the need to consider bacterial purulent infections in the treatment of patients with CL, in order to receive a comprehensive treatment of their disease. Important and exciting work is on the way in endemic areas for cutaneous leishmaniasis that will improve quality live of those who unfortunately suffer from this disease.

\section{ACKNOWLEDGEMENTS}

To health authorities of the State of Campeche, to the former Health Minister of Campeche Dr Fernando Sandoval for their valuable assistance provided to develop this work and the staff of the University of Campeche for their technical assistance. To Dr Gustavo Acosta A for the gift of kits for immunocolorimetric detection of Streptococcus group A.

\section{REFERENCES}

Cheesbrough M 1989. Medical Laboratory Manual for Tropical Countries, Vol. II, Microbiology, Butterworths, Great Britain.

Couppie P, Pradinaud R, Grosshans E, Sainte-Marie D, Benoist B 1997. Rapid diagnosis of cutaneous leishmaniasis and histoplasmosis by direct microscopic tests. Ann Dermatol Venereol 124: 849-851.

Edrissian GH, Mohammad M, Kanani A, Afshar A, Hafezi R, Ghorbani M, Gharagozloo AR 1990. Bacterial infections in suspected cutaneous leishmaniasis lesions. Bull WHO 68: 473-477.

El-On-J, Sneier R, Elias-E 1992. Leishmania major. Bacterial contamination of cutaneous lesions in experimental animals. Isr J Med Sci 28: 847-851.

Grasa JM, Lorente J, Crego F, Naches S, Subirana FX, Calderon JR, Pollan C, Encarnacion LF, Quesada P 2000. Nasal leishmaniasis in an HIV-positive patient. Acta Otorrinolaringol Esp 51: 169-173.

Kawabata M, Mimori T, Gomez EA, Hashiguchi Y 1995. Flora bacteriana aislada de dos tipos de úlceras leishmaniásicas en Ecuador. In Y Hashiguchi, Estudios sobre la Leishmaniasis en el Nuevo Mundo y su Transmisión, con Especial Referencia al Ecuador, Serie de Reportes de Investigación No. 1, Kyowa Printing, Japan, p. 68-71.

Lezama-Dávila CM, Isaac-Márquez AP, Padierna-Olivos J, Aguilar-Torrentera F, Chapa-Ruiz R 1998. Immunomodulation of chiclero's ulcer. Role of eosinophils, T cells, tumour necrosis factor and interleukin-2. Scand $J$ Immunol 47: 502-508.

Nega B, Asrat H, Yodit A, Yewondwosen T, Knut B, Yegeremu A 2001. Inter-current and nosocomial infections among visceral leishmaniasis patients in Ethiopia: an observational study. Acta Trop 80: 87-95.

Pérez-Mutul J, Balam TL, Canto LS 1994. Identificación de protozoarios del género leishmania con sondas biotinadas de kDNA en la peninsula de Yucatán. Rev Biomed 5: 60-69.

Potter ME, Chapman WL, Hanson WL, Blue JL 1983 Leishmania braziliensis: effect of bacteria ( $S$. aureus, $P$. multocida) on the developing cutaneous leishmaniasis lesions in the golden hamster. Exp Parasitol 56: 107118.

Roth RR, James WD 1988. Microbial ecology of the skin. Annu Rev Microbiol 42: 441-464.

Shankar AH, Titus RG 1995. T-cell and non-T cell compartments can independently determine resistance to L. major. J Exp Med 181: 845-855. 